\title{
$O$-Glycosylation of Proteins by Membrane Fractions of Trichoderma reesei QM 9414
}

\author{
By JOANNA KRUSZEWSKA, ${ }^{1}$ ROBERT MESSNER, ${ }^{1}$ \\ CHRISTIAN P. KUBICEK ${ }^{2}$ AND GRAZYNA PALAMARCZYK ${ }^{1}$ * \\ ${ }^{1}$ Institute of Biochemistry and Biophysics, Polish Academy of Sciences, Warsaw, Poland \\ ${ }^{2}$ Department of Microbial Biochemistry, Institute of Biochemical Technology and Microbiology, \\ University of Technology, Vienna, Austria
}

(Received 18 July 1988; revised 26 September 1988; accepted 10 October 1988)

\begin{abstract}
In order to investigate $O$-glycosylation of proteins in the fungus Trichoderma reesei QM 9414, a membrane preparation was isolated and used to study the glycosylation of endogenous proteins. Exogenously added GDP-[U-14 C]mannose was used to mannosylate both endogenous lipid and protein. The kinetics of mannosylation together with pulse-chase experiments with cold GDPmannose revealed that lipid was labelled before protein. The lipid was identified as mannosyl phosphoryl dolichol (Dol-P-Man) by TLC together with an authentic standard from yeast. Addition of tsushimycin, a specific inhibitor of Dol-P-Man synthesis, completely blocked transfer of mannose from GDP-[U-14 C]mannose to endogenous lipid. The mannosyl units transferred to endogenous protein could be released by $\beta$-elimination, and were shown to consist mainly of tetra-, di- and monomannosyl chains. Mannosylation of endogenous proteins occurred at a lower rate with membranes isolated from glycerol-grown cells. This could be overcome by addition of cold GDP-mannose, suggesting a limitation of endogenous GDP-mannose and/or dolichol phosphate in glycerol-grown (i.e. catabolite-repressed) cells.
\end{abstract}

\section{INTRODUCTION}

Trichoderma reesei is a filamentous fungus which is of considerable interest because of its ability to secrete various proteins in high amounts and at a high rate (i.e. cellulases and hemicellulases; Mandels, 1985). The biochemistry of its secretory pathway, however, is still poorly defined, and little is known about control of secretion. Analysis of enzymes and their genes clearly established that all cellulases so far characterized (cellobiohydrolase I and II, endoglucanase I and III) contain both $\mathrm{N}$ - as well as $\mathrm{O}$-linked carbohydrate (Gum \& Brown, 1976; Fägerstam et al., 1984; Salovuori et al., 1987; Enari \& Niku-Paavola, 1987; Knowles et al., 1987). Merivuori et al. (1985) reported that $N$-glycosylation is not required for secretion of proteins by $T$. reesei, but adds to their stability. Kubicek et al. (1987) reported that $O$-linked, but not $N$-linked glycosylation is obligatory for secretion of endoglucanases by $T$. reesei. This was further supported by Messner \& Kubicek (1988), by studying the kinetics of accumulation of endoglucanase precursor proteins inside $T$. reesei prior to secretion. Furthermore, $O$-linked carbohydrate may be involved in binding of cellulases to cellulose (Van Tilbeurgh et al., 1986; Tomme et al., 1988).

The pathway of $O$-glycosylation in yeast and other fungi is unique among eukaryotes as it involves dolichol phosphate (Dol-P) and occurs at the endoplasmic reticulum (Tanner \& Lehle,

Abbreviations: Dol-P, dolichol phosphate; Dol-P-Man, mannosyl phosphoryl dolichol. 
1987). Only a few filamentous fungi have, however, been investigated in this respect (Letoublon \& Got, 1974; Gold \& Hahn, 1976; Gander et al., 1977; Soliday \& Kolattokudy, 1979). In the present paper we describe the introduction of $O$-glycosidically linked mannosyl units into proteins by a membrane fraction of $T$. reesei QM 9414 .

\section{METHODS}

Organism and growth conditions. Trichoderma reesei QM 9414 was maintained on malt agar slants. Inocula were prepared by harvesting 14-d-old conidia in sterile tap water containing $0 \cdot 1 \%(\mathrm{w} / \mathrm{v})$ Tween 80 . The conidia were added to the medium to give a final concentration of $10^{8}$ conidia $1^{-1}$. The fungus was grown in shake flasks on a rotary shaker (250 r.p.m.) at $28^{\circ} \mathrm{C}$ in the medium described by Mandels \& Andreotti (1978), except that the carbon source (glycerol or lactose, as indicated) was used at $0.5 \%(\mathrm{w} / \mathrm{v})$ and the $\mathrm{pH}$ of the medium was kept at 5.0 with phosphate/citrate buffer as described by Labudova \& Farkas (1983). Samples (200 ml) of this medium were added to 1 litre wide-mouthed Erlenmeyer flasks.

Cell fractionation. After $22 \mathrm{~h}$ of growth, the contents from five flasks were harvested by suction filtration; the mycelia (8-12 $\mathrm{g}$ wet weight) were suspended in $150 \mathrm{ml} 50 \mathrm{mM}-\mathrm{Tris} / \mathrm{HCl}$ buffer, containing $15 \mathrm{mM}-\mathrm{MgCl}_{2}$ and $9 \mathrm{mM}$-2-mercaptoethanol, $\mathrm{pH} \mathrm{7.4}$, and then homogenized in a Beadbeater with glass beads of $0.5 \mathrm{~mm}$ diameter (Biospec Products) as described by Cramer et al. (1983). The homogenate was centrifuged at $1000 \mathrm{~g}$ for $10 \mathrm{~min}$, $14000 \mathrm{~g}$ for $20 \mathrm{~min}$ and then at $40000 \mathrm{~g}$ for $20 \mathrm{~min}$ to yield a membrane fraction. The $40000 \mathrm{~g}$ pellet was resuspended in homogenization buffer (see above), and was used in all further experiments. Marker enzymes (vanadate sensitive and insensitive ATPase, glucose-6-phosphatase and cytochrome $c$ reductase) were assayed as described by Borgeson \& Bowman (1983). Protein was determined according to Bradford (1976).

Incorporation of $\left[{ }^{14} \mathrm{C}\right]$ mannose into Dol-P. Mannosyl transfer from GDP-[U-14 $\left.\mathrm{C}\right]$ mannose to endogenous Dol-P was measured in a $40 \mu \mathrm{l}$ reaction mixture containing $50 \mathrm{mM}$-Tris/ $\mathrm{HCl}$, pH 7.4, $125 \mathrm{mM}-\mathrm{MgCl}_{2}$ (or $\mathrm{MnCl}_{2}$ where indicated), 70000 c.p.m. GDP-[U-1 ${ }^{14}$ C]mannose [specific activity $\left.146 \mathrm{mCi} \mathrm{mmol}^{-1}\left(5.4 \mathrm{GBq} \mathrm{mmol}^{-1}\right)\right], 0.125 \%$ (w/v) Triton X-100 and 0.15-0.6 mg enzyme protein. After incubation at $30^{\circ} \mathrm{C}$ for $60 \mathrm{~min}$ (unless otherwise indicated) the reaction was stopped by the addition of $2 \mathrm{ml}$ chloroform/methanol $(3: 2, \mathrm{v} / \mathrm{v})$. Formation of Dol-PMan was measured as described by Sharma et al. (1974).

Characterization of the mannosyl lipid. The chloroform/methanol extract was subjected to mild alkaline hydrolysis (see below) and the remaining lipid fraction chromatographed on a DEAE-Sephadex column $(0.8 \times 10 \mathrm{~cm})$ as follows. After applying the sample, the column was washed with $10 \mathrm{ml}$ each of: $(a)$ chloroform/methanol $(2: 1, \mathrm{v} / \mathrm{v}) ;(b) 10 \mathrm{mM}$-ammonium acetate in $(a) ;(c) 50 \mathrm{mM}$-ammonium acetate in $(a) ;(d)$ $100 \mathrm{~mm}$-ammonium acetate in $(a)$. The desired fractions were evaporated to dryness, the residue was dissolved in chloroform, and ammonium acetate was removed by extraction with water. Fractions containing radioactivity were subjected to TLC on Silica Gel G plates using either chloroform/methanol/water $(65: 25: 4$, by vol.) (solvent A) or di-isobutyl ketone/acetic acid/water $(60: 45: 6$, by vol.) (solvent B) as mobile phases. Radioactive material was localized by autoradiography, and compared with authentic standards.

Transfer of mannosyl residues from $\left[U-{ }^{14} \mathrm{C}\right]$ mannosyl phosphoryl dolichol to endogenous protein. $\left[\mathrm{U}-{ }^{14} \mathrm{C}\right] \mathrm{Mannosyl}$ phosphoryl dolichol (Dol-P-Man) (50000 c.p.m.) was dried under nitrogen, resuspended in $30 \mathrm{mM}-\mathrm{Tris} / \mathrm{HCl}$ pH 7.4, containing $9 \mathrm{~mm}-\mathrm{MgCl}_{2}, 7 \mathrm{mM}-\mathrm{MnCl}_{2}$ and $0.28 \%(\mathrm{w} / \mathrm{v})$ Triton X-100. Enzyme protein was then added and the mixture was incubated for $60 \mathrm{~min}$ at $30^{\circ} \mathrm{C}$. The reaction was stopped by addition of $2 \mathrm{ml}$ chloroform/methanol $(3: 2, \mathrm{v} / \mathrm{v})$. After centrifugation $\left(3000 \mathrm{~g}, 4^{\circ} \mathrm{C}, 15 \mathrm{~min}\right)$ the supernatant was carefully removed and the pellet thoroughly washed with chloroform/methanol $(3: 2, \mathrm{v} / \mathrm{v})$, then with chloroform/methanol/ water $\left(10: 10: 3\right.$, by vol.) and finally with chloroform/methanol/4 $\mathrm{mM}-\mathrm{MgCl}_{2}(10: 3: 3$, by vol.). Radioactivity incorporated into protein was measured as described by Sharma et al. (1974).

Characterization of the glycoprotein. The protein pellet was subjected to $\beta$-elimination essentially as described by Gold \& Hahn (1976), and then lyophilized; the carbohydrates released were identified by TLC on DC-cellulose plastic plates in butanol/ethyl acetate/acetic acid/water $(40: 30: 25: 40$, by vol.). Distribution of radioactivity was identified with a TLC scanner or by autoradiography.

For characterization of glycoproteins by electrophoresis, the protein pellets were washed twice with $1 \mathrm{ml}$ ethanol, and then taken up in $0.5 \mathrm{ml} 0.1 \mathrm{M}$-Tris/HCl buffer, $\mathrm{pH} 6.8$, containing $3 \%(\mathrm{w} / \mathrm{v})$ SDS and $5 \%(\mathrm{w} / \mathrm{v}) 2-$ mercaptoethanol, and heated in a boiling water-bath for $10 \mathrm{~min}$. After centrifugation in an Eppendorf centrifuge, the supernatants were subjected to SDS-PAGE (Laeminli, 1970). Following electrophoresis, the gels were either prepared for autoradiography as described previously (Kubicek, 1987), or blotted onto nitrocellulose paper and stained for cellobiohydrolase I by means of a monoclonal antibody (Mischak et al., 1989).

Materials. GDP-[U. $\left.{ }^{14} \mathrm{C}\right] \mathrm{Mannose}\left[100-200 \mathrm{mCi} \mathrm{mmol}^{-1}\left(3 \cdot 7-7 \cdot 4 \mathrm{GBq} \mathrm{mmol}^{-1}\right)\right]$ was from Amersham. $\mathrm{C}_{95}$ Dol-P was obtained from the collection of polyprenols of the Institute of Biochemistry and Biophysics, Warsaw, Poland. TLC plates were from Merck. All other chemicals were of analytical grade and were obtained from commercial sources. Tsushimycin was a gift from Dr A. D. Elbein (The University of Texas, San Antonio, USA). 


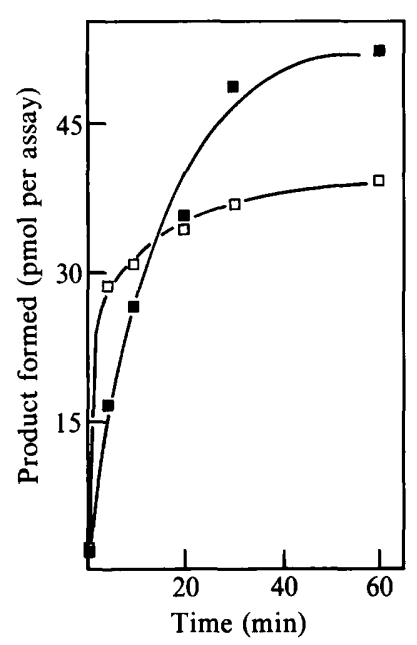

Fig. 1

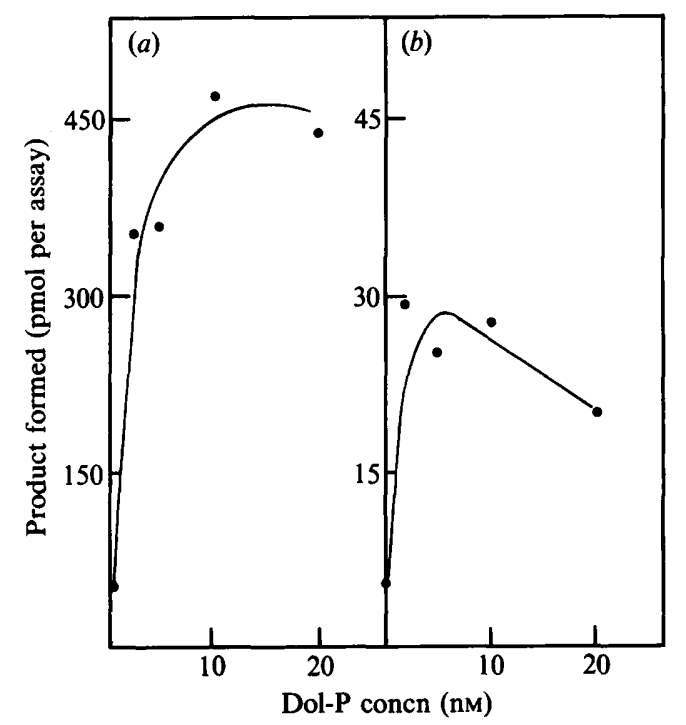

Fig. 2

Fig. 1. Time dependence of the transfer of mannose from GDP-[U-14 C]mannose to endogenous lipid ( $\square)$ and protein $(\square)$.

Fig. 2. Effect of Dol-P concentration on the incorporation of mannose from GDP-[U- $\left.{ }^{14} \mathrm{C}\right] \mathrm{mannose}$ into lipid $(a)$ and protein $(b)$.

\section{Table 1. Mannosyl transfer from GDP-[U-14C]mannose into lipid and protein}

Conditions for mannosyl transfer are described in Methods. Where indicated, unlabelled GDPmannose $(4 \mu \mathrm{mol})$ was added after $60 \mathrm{~min}$ and the reaction continued for a further $60 \mathrm{~min}$.

$\begin{array}{lcc}\quad \text { Conditions } & \overbrace{\text { Lipid }}^{\text {(pmol per assay) in: }} & \text { Protein } \\ \begin{array}{l}\text { No GDP-mannose } \\ \text { GDP-mannose }\end{array} & 372 & 7.9 \\ \begin{array}{l}\text { GDP-mannose } \\ +350 \mu \mathrm{g}\end{array} & 190 & 52.0 \\ \text { tsushimycin } \mathrm{ml}^{-1} & <2 & <2.0 \\ & & \end{array}$

\section{RESULTS}

\section{Mannosyl transfer from GDP-[U-14 C]mannose to lipid and glycoprotein fractions}

Incubation of the $T$. reesei microsomal fraction with GDP-[U-14 C]mannose at $30^{\circ} \mathrm{C}$ resulted in the incorporation of radioactivity into two endogenous acceptors (Fig. 1); the initial rate of formation of the mannosyl-lipid was faster than the initial rate of formation of the mannosylprotein. This time-course is consistent with the notion that mannose is transferred from GDPmannose to the protein via a lipid intermediate. Further support for this was obtained by carrying out a pulse-chase with cold GDP-mannose (Table 1): this led to a decrease in label in the lipid fraction with a concomitant increase in label in the protein.

Tsushimycin, a specific inhibitor of the synthesis of Dol-P-Man from GDP-mannose (Elbein, 1981), virtually blocked incorporation of $\left[\mathrm{U}^{-14} \mathrm{C}\right]$ mannose into both lipid and protein (Table 1). It seems, therefore, that the lipid intermediate is indeed Dol-P-Man and that protein mannosylation occurs via this lipid intermediate. 


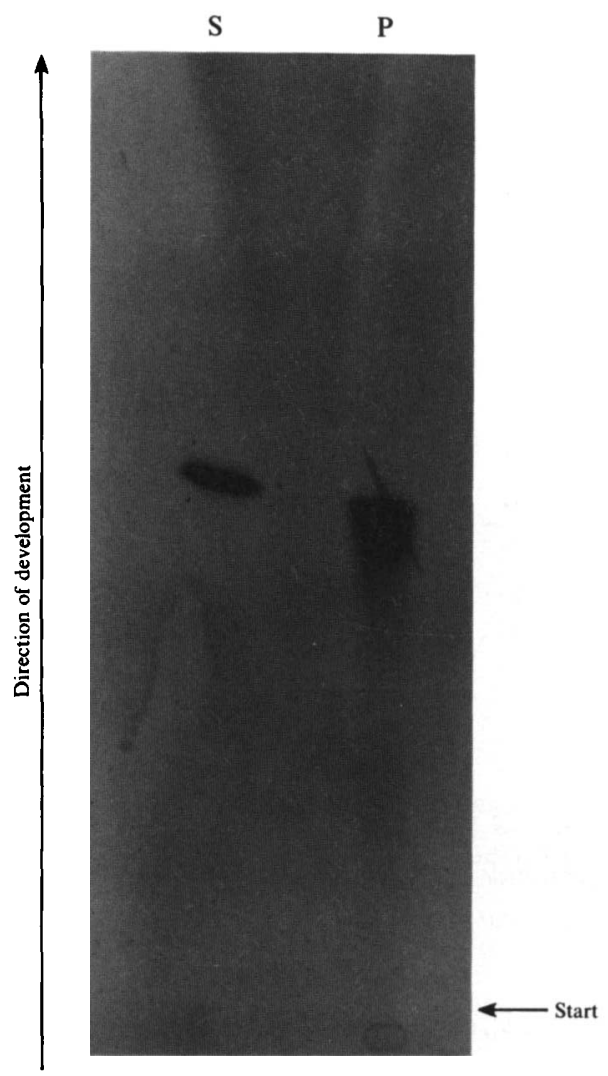

Fig. 3. Chromatographic characterization of $T$. reesei mannosyl lipid. The samples were separated by TLC using solvent $A$, and the chromatogram was then autoradiographed. S, standard (Dol-P-Man from yeast); $\mathrm{P}$, sample isolated from $T$. reesei membrane fractions after incubation with GDP-[U-14 C]mannose as described in Methods.

These initial results implied a mechanism of $O$-glycosylation analogous to that in $S$. cerevisiae (Tanner \& Lehle, 1987), in which Dol-P-Man donates the first $O$-linked mannose unit. Direct evidence for such a mechanism came from experiments in which transfer of mannose from DolP-Man to endogenous protein, present in the $T$. reesei membrane fractions, was demonstrated (Table 2). Interestingly, mannosyl transfer was significantly higher when membranes were prepared from $T$. reesei grown under conditions of carbon catabolite derepression (lactose as carbon source): this difference was almost abolished when the reaction system was supplemented with exogenous cold GDP-mannose.

The activity of the enzyme transferring mannose from GDP-mannose to Dol-P was also higher in cells grown under conditions of carbon catabolite derepression. Transfer of [U$\left.{ }^{14} \mathrm{C}\right]$ mannose from GDP-[U-14 $\left.\mathrm{C}\right]$ mannose to lipid as well as to protein increased linearly with increasing amounts of membrane protein up to $0.8 \mathrm{mg}$ protein.

The transfer of mannose to the lipid fraction was strongly increased by addition of exogenous $\mathrm{C}_{95}$-Dol-P (Fig. 2). From these data, the apparent $K_{\mathrm{m}}$ was found to be $2-5 \mathrm{nM}$.

\section{Characterization of the labelled glycolipid}

The mannosyl lipid synthesized by membranes of $T$. reesei was analysed by methods similar to those used to identify Dol-P-Man in other filamentous fungi (Letoublon \& Got, 1974; Gold \& Hahn, 1976; Gander et al., 1977; Soliday \& Kolattokudy, 1979). DEAE-Sephadex chromatography showed that the glycolipid from $T$. reesei cochromatographed with a Dol-P- 


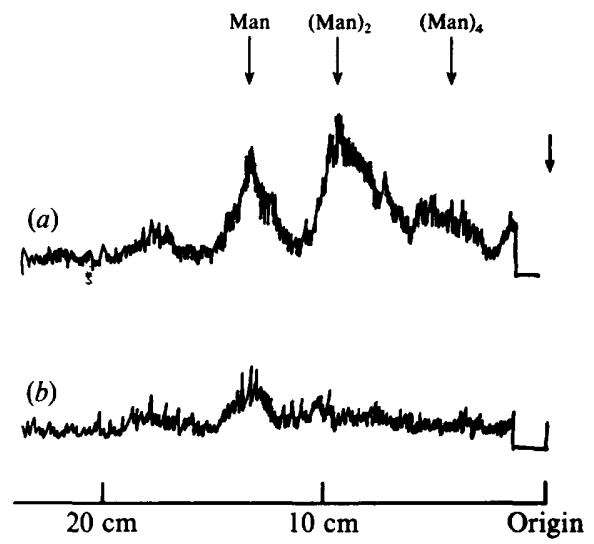

Fig. 4. TLC radioactivity scan of oligomannosides, released by $\beta$-elimination from endogenous proteins mannosylated in the presence of $\mathrm{Mn}^{2+}(a)$ or $\mathbf{M g}^{2+}(b)$. The position of the oligosaccharide markers is indicated.

Table 2. Transfer of $\left[U-{ }^{14} C\right]$ mannose from $\left[U-{ }^{14}\right]$ mannosyl $C_{95}$-dolichol phosphate into endogenous protein

Membrane fractions were isolated from $T$. reesei grown in a medium containing glycerol (carbon repressed) or lactose (carbon derepressed); the fractions (370 or $390 \mu \mathrm{g}$ protein, respectively) were incubated with 56000 c.p.m. [U-14 ${ }^{14}$ ]mannosyl $\mathrm{C}_{95}$-dolichol phosphate for $120 \mathrm{~min}$ and radioactivity incorporated into protein was measured, all as described in Methods. Where indicated, unlabelled GDP-mannose $(4 \mu \mathrm{mol})$ was added after $60 \mathrm{~min}$, and the reaction allowed to proceed for a further $60 \mathrm{~min}$.

$\begin{array}{ccr}\begin{array}{c}\text { Carbon } \\ \text { source }\end{array} & \begin{array}{c}\text { Presence/absence } \\ \text { of GDP-mannose }\end{array} & \begin{array}{r}{\left[\mathrm{U}-{ }^{14} \mathrm{C}\right] \mathrm{M}} \\ \text { incorporated in } \\ \text { (pmol in } 120\end{array} \\ \text { Glycerol } & - & 2 \cdot 4 \\ & + & 12.4 \\ \text { Lactose } & - & 8.5 \\ & + & 13 \cdot 1\end{array}$

Man standard synthesized from GDP-mannose and $\mathrm{C}_{90}$-Dol-P yeast mannosyl transferase. Two different (neutral and acid) solvent systems revealed a single labelled band with $R_{F}$ values similar to those for yeast Dol-P-Man (Fig. 3).

\section{Characterization of the oligosaccharides transferred to the glycoprotein}

To determine the size and linkage of the carbohydrates introduced into membrane protein, the glycoprotein fraction was subjected to $\beta$-elimination. Approximately $90 \%$ of the label in the protein fraction was released by this procedure. TLC of the released oligosaccharides showed (Fig. 4) that they consisted of mannose, dimannosides and tetramannosides (as checked against appropriate standards). These findings are consistent with the conclusion that $T$. reesei membrane fractions carry out $O$-glycosylation of endogenous protein acceptors. As described in other systems (Tanner \& Lehle, 1987), synthesis of oligomannosides is dependent on the presence of $\mathrm{Mn}^{2+}$ ions in the system. In the presence of $\mathrm{Mg}^{2+}$, the released carbohydrate portion consisted mainly of mannose (Fig. 4).

\section{Demonstration of the presence of $\mathrm{CBH} I$ in $T$. reesei membrane fractions}

In order to support the conclusion that $T$. reesei cellulases, which carry $O$-glycosidically linked mannose chains (Fägerstam et al., 1984; Salovuori et al., 1987; Gum \& Brown, 1976), are actually located in the membrane fractions studied here, membrane protein was subjected to SDS-PAGE and the major cellobiohydrolase, CBH I, detected with a monoclonal antibody (Mischak et al., 1989). Immunostaining revealed a band at 60-70 kDa (Fig. 5); this corresponds 


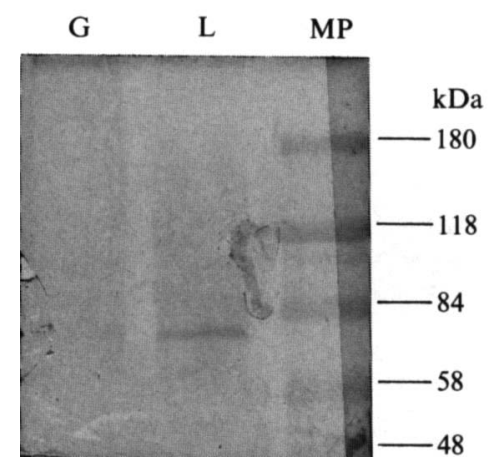

Fig. 5. SDS-PAGE/Western blotting and immunostaining of endogenous proteins isolated from $T$. reesei membranes after incubation with GDP- $\left[\mathrm{U}-{ }^{14} \mathrm{C}\right]$ mannose. $\mathrm{L}$, membranes isolated from lactosegrown cells; G, membranes isolated from glycerol-grown cells; PM, prestained marker proteins (Sigma).

to the size reported for glycoslyated CBH I (Salovuori et al., 1987). CBH I was present in membranes from mycelia grown under carbon-catabolite-repressed (glycerol) as well as derepressed (lactose) conditions. Fluorography of the SDS-PAGE gels revealed diffuse bands of radioactivity in the 60-70 kDa molecular mass area (not shown); hence it cannot be claimed that CBH I was in fact glycosylated in our in vitro system.

\section{DISCUSSION}

The present report offers evidence that a membrane fraction from $T$. reesei mycelia catalyses the transfer of mannose from GDP-mannose to endogenous lipid acceptors and subsequently to endogenous protein. Pulse-chase experiments, the kinetics of incorporation and the use of exogenously added Dol-P-Man all suggested that Dol-P-Man functions as an intermediate in the transfer of mannose from GDP-mannose to protein; hence, $O$-glycosylation in $T$. reese $i$ is by a mechanism similar to that previously demonstrated in other fungi (Tanner \& Lehle, 1987). The mannose incorporated was mainly found in Dol-P-Man, and tsushimycin, which specifically inhibits Dol-P-Man formation, completely inhibited mannosyl transfer in our preparations.

So far, the endogenous mannosyl accepting proteins that are labelled by $\left[\mathrm{U}-{ }^{14} \mathrm{C}\right] \mathrm{mannose}$ have not been identified. Soliday \& Kolattokudy (1979) showed that in Fusarium solani, mannosyl residues were incorporated into microsomal proteins that had the same molecular mass as the major secretory proteins of this fungus. Although our membrane fractions contained CBH I protein, we could not demonstrate that this protein was a substrate for glycosylation in vitro. This could be due to the fact that $\mathrm{CBH}$ I contained in the membranes should already bear both $N$ - as well as $O$-glycosidically linked sugar chains, and thus be unaccessible to further glycosylation. However, exogenously added CBH I (purified and deglycosylated) also was not glycosylated, probably because of the lack of translation activity and membrane integrity in our in vitro system. Further studies using cell-free translation systems in combination with our membrane fractions may succeed in glycosylating cellulases in vitro.

The biological role of $O$-glycosylation in fungi has not yet been elucidated. We recently postulated that $O$-glycosylation of cellulases is one of the parameters controlling their secretion (Kubicek et al., 1987; Messner \& Kubicek, 1988). In this paper we have shown that incorporation of mannose into protein from Dol-P-Man is greater in carbon-catabolitederepressed mycelia than in carbon-catabolite-repressed mycelia. However, this difference was eliminated by adding cold GDP-mannose., This may be interpreted in terms of the presence of lower concentrations of Dol-P-Man and GDP-mannose in carbon-catabolite-repressed mycelia. The previously observed lag in $O$-glycosylation of $T$. reesei endoglucanases during induction of synthesis by sophorose supports this hypothesis (Messner \& Kubicek, 1988). The concentration of Dol-P in the endoplasmic reticulum has been shown to be rate limiting to glycosylation in several cell systems (Burton et al., 1979; Schwarz \& Datema, 1982). The above findings, together 
with the fact that CBH I was clearly present (although in lower concentrations) in microsomes isolated from glucose-grown mycelia, would suggest that $O$-glycosylation may - at least in part be involved in catabolite repression of CBH I synthesis.

\section{REFERENCES}

BORGESON, C. E. \& Bowman, B. J. (1983). Isolation and characterization of the Neurospora crassa endoplasmic reticulum. Journal of Bacteriology 156, 362-368.

BRADFORD, M. M. (1976). A rapid and sensitive method for the quantitation of microgram quantities of protein utilizing the principle of protein-dye binding. Analytical Biochemistry 72, 248-254.

Burton, W. A., Scher, M. G. \& WAEchter, C. J. (1979). Enzymatic phosphorylation of dolichol in central nervous tissue. Journal of Biological Chemistry 254, 7129-7136.

Cramer, C. L., Ristow, J. L., Paulus, T. J. \& Davis, R. H. (1983). Methods for mycelial breakage and isolation of mitochondria and vacuoles of Neurospora. Analytical Biochemistry 128, 384-392.

Elbein, A. D. (1981). The effect of tsushimycin on the synthesis of lipid linked saccharides in aorta. Biochemical Journal 193, 477-484.

EnARI, T. M. \& NikU-PaAvola, M. L. (1987). Enzymatic cellulose hydrolysis. CRC Critical Reviews in Biotechnology 5, 67-87.

Fägerstam, L. G., Petterson, L. G. \& Engstrom, J. A. (1984). The primary structure of a 1,4- $\beta$-glucan cellobiohydrolase from the fungus Trichoderma reese $i$ QM 9414. FEBS Letters 167, 309-315.

Gander, J. E., Drewes, L. R., FANG, F. \& Lui, A. (1977). 5- $O-\beta$-D-Galactofuranosyl-containing exocellular glycopeptide of Penicillium charlesii. Incorporation of mannose from GDP-mannose into glycopeptide. Journal of Biological Chemistry 252, 2187-2193.

GoLD, M. H. \& HAHN, H. J. (1976). Role of mannosyl lipid intermediate in the synthesis of Neurospora crassa glycoproteins. Biochemistry 15, 1808-1814.

GUM, E. K. \& BRown, R. D., JR (1976). Structural characterization of a glycoprotein cellulase 1,4- $\beta$-Dglucan cellobiohydrolase $\mathrm{C}$ from Trichoderma viride. Biochimica et biophysica acta 446, 371-386.

Knowles, J., LeHtovaARA, P. \& TeERI, T. T. (1987). Cellulase families and their genes. Trends in Biotechnology 5, 255-261.

KUBICEK, C. P. (1987). Involvement of a conidial endoglucanase and a plasma membrane bound $\beta$ glucosidase in the induction of endoglucanase synthesis by cellulose in Trichoderma reesei. Journal of General Microbiology 133, 1481-1487.

Kubicek, C. P., Panda, T., Schreferl-Kunar, G., Messner, R. \& GRUBER, F. (1987). O-Linked - but not $N$-linked glycosylation is necessary for secretion of endoglucanase I and II by Trichoderma reesei. Canadian Journal of Microbiology 33, 698-703.

LABUDOVA, I. \& FARKAS, V. (1983). Multiple enzyme forms in the cellulase system of Trichoderma reesei during its growth on cellulose. Biochimica et biophysica acta 744, 135-140.

LAEMMLI, U. K. (1970). Cleavage of structural proteins during the assembly of the head of bacteriophage T4. Nature, London 227, 680-685.

Letoublon, R. \& Got, R. (1974). Role d'un intermediaire lipidique dans le transfert du mannose a des accepteurs glycoproteiques endogenez chez Aspergillus niger. FEBS Letters 46, 214-217.

MANDELS, M. (1985). Application of cellulases. Biochemical Society Transactions 13, 414-416.

Mandels, M. \& ANDreotTi, R. E. (1978). Problems and challenges in the cellulose to cellulase fermentation. Process Biochemistry 13, 6-13.

Merivuori, H., SANDS, J. A. \& Montenecourt, B. S. (1985). Effects of tunicamycin on secretion and enzymatic activities of cellulase from Trichoderma reesei. Applied Microbiology and Biotechnology 23, 60-66.

MesSneR, R. \& KubiceK, C. P. (1988). Intracellular precursors of endo- $\beta$-1,4-glucanase in Trichoderma reesei. FEMS Microbiology Letters 50, 227-232.

Mischak, H., Hofer, F., Messner, R., Weissinger, E., Hayn, M., TOMme, P., Esterbauer, H., Küchler, E., Clayessens, M. \& Kubicek, C. P. (1989). Monoclonal antibodies against different domains of cellobiohydrolase I and II from Trichoderma reesei. Biochimica et biophysica acta (in the Press).

Palamarczyk, G., Lehle, L., Mankowski, T., ChoJNACKI, T. \& TANNER, W. (1980). Specificity of solubilized yeast glycosyl transferases for polyprenyl derivatives. European Journal of Biochemistry 105, 517-523.

Salovuori, I., Makarow, M., Rauvala, H., KNOWLES, J. \& KäÄRIÄINEN, L. (1987). Low molecular weight high-mannose type glycans in a secreted protein of the filamentous fungus Trichoderma reesei. Bio/Technology 5, 152-156.

Schwarz, R. T. \& DATEMA, R. (1982). The lipid pathway of protein glycosylation and its inhibitors: the biological significance of protein bound carbohydrate. Advances in Carbohydrate Chemistry 40, 287-379.

ShaRma, C. B., BabCZinski, L., Lehle, L. \& TANNER, W. (1974). The role of dolichol monophosphate in glycoprotein biosynthesis in Saccharomyces cerevisiae. European Journal of Biochemistry 46, 35-41.

Soliday, C. L. \& Kolattokudy, P. E. (1979). Introduction of $O$-glycosidically linked mannose into proteins via mannosyl phosphoryl dolichol by microsomes from Fusarium solani f. pisi. Archives of Biochemistry and Biophysics 197, 367-378.

TANNER, W. \& LEHLE, L. (1987). Protein glycosylation in yeast. Biochimica et biophysica acta 906, 81-99.

Tomme, P., Van Tilbeurgh, H., Petterson, G. L., VAN DAMMe, J., VANDEKerCKhove, J., KNowles, J., Teeri, T. T. \& Claeyssens, M. (1988). Studies of the cellulolytic system of Trichoderma reesei QM 9414. Analysis of domain function in two cellobiohydrolases by limited proteolysis. European Journal of Biochemistry 170, 575-581.

Van Tilbeurgh, H., Tomme, P., Claeyssens, M., BhikhabHai, R. \& PetTerson, G. L. (1986). Limited proteolysis of the cellobiohydrolase I from Trichoderma reesei. Separation of functional domains. FEBS Letters 204, 223-227. 